\title{
Project-Based Learning as a Tool for Sounding Perception and Developing Socio-Emotional Skills in 4th-Grade Students
}

\author{
Angélica M. M. Freitas, Bianca C. Rossi, Sandra G. Pereira, Marcos Roberto Dos Santos, \\ Carlos A. M. Dos Santos, Marco Antonio C. Pereira
}

Programa de Pós-graduação em Projetos Educacionais de Ciências (PPGPE), Escola de Engenharia de Lorena (EEL), Universidade de São Paulo (USP), Lorena, SP, Brazil

Email: cams@demar.eel.usp.br

How to cite this paper: Freitas, A. M. M., Rossi, B. C., Pereira, S. G., Dos Santos, M. R., Dos Santos, C. A. M., \& Pereira, M. A. C. (2019). Project-Based Learning as a Tool for Sounding Perception and Developing Socio-Emotional Skills in 4th-Grade Students. Creative Education, 10, 1444-1455. https://doi.org/10.4236/ce.2019.107106

Received: May 13, 2019

Accepted: July 8, 2019

Published: July 11, 2019

Copyright $\odot 2019$ by author(s) and Scientific Research Publishing Inc. This work is licensed under the Creative Commons Attribution International License (CC BY 4.0).

http://creativecommons.org/licenses/by/4.0/

\begin{abstract}
This reports an analysis of the application of Project-Based Learning (PBL) methodology with a group of 17 students of the 4th grade of an elementary school at Taubaté town, São Paulo State, Brazil. The objective was to teach concepts related to noise pollution in order to educate kids committed to the environment. The project was developed with teams using eight stages applied between April and June of 2018. The social-emotional skills were observed at all stages, which contributed to the development of the concept of pollution. Although some students had shown difficulties to work in teams, they finished their activities and recognized their needs to improve collaboration. In addition, they also understood the dangers of noise pollution and the importance of changing habits in their daily lives.
\end{abstract}

\section{Keywords}

Elementary School, Environment, Sound Perception

\section{Introduction}

Due to the disorderly advances of the cities, human beings have generated a great environmental imbalance due to the exploitation of natural resources to meet their needs, changing the nature landscape considerably, resulting in many problems (Rampazzo, 1996), such as production of garbage, damage to other species, and pollution (Grün, 1996).

Among all these aggressions to the environment, noise pollution can be highlighted, since it is considered the third largest environmental pollution and has 
an influence on the people's live without leaving visible traces of their effect on the environment (Lima et al., 2014). Furthermore, it directly affects the population quality of life, since excessive levels of noise are capable of producing discomfort and causing health harm to the ear and possibly brain disturbs (Machado, 2004).

According to the World Health Organization, the allowed noise level is $50 \mathrm{~dB}$, with $55 \mathrm{~dB}$ already considered causing disturbances, as it may cause difficulty for the communication and damage to health (Zajarkiewicch, 2010), as well as causing disturbances during sleeping, and other effects, such as irritability, fatigue, high levels of stress, and difficulty of concentration (Rios, 2003).

Even with all the problems caused by the noise, it should be noted that it is always present in the landscape sound. The landscape sound is the composition of all the sounds present in a certain place, taking into account the sum of all sound level, people's perception of the sound, the unpleasant and pleasant sounds, and the spatial factors (Schafer, 2009), such as influence of trees and buildings.

Nowadays, in all parts of the world, the landscape sound is changing, as sounds are increasing fast, producing a noisier environment. There is growing evidence that modern civilization may be deafening because of noise (Schafer, 2001). These high levels of noise can be caused by the agglomerations of people, vehicles, houses, night bars, advertising cars, recreation, among others (Eniz, 2004).

In order to change the current scenario on noise pollution, it is important to develop a practical educational project, based upon current conceptions of teaching and learning in music, focusing on a sound experience, individual and collective creation, in order to develop a new sounding composition in the society (Schafer, 1991).

Additionally, the development of practical projects with students of the Elementary School, in an interdisciplinary way, contributes to the cognitive, socialization, and citizenship development of the children, since they learn, even from early ages, that they need to take care and preserve Mother Nature (Medeiros et al., 2011).

In such a way, the main objective of the present project is to teach 4th-grade students on concepts related to the noise pollution, using the Project-Based Learning (PBL) methodology. Besides that, the project proves to develop social-emotional skills of the students as well as educate them to be committed with future of the planet.

\section{Socio-Emotional Skills and Team Working}

The basic aspect of the PBL is the work in teams. To do so, it is necessary to exercise students' emotional skills, since the presence or lack of them will have a significant influence on the work of small or large teams.

Focusing on emotional skills, it is necessary to make an integral formation of the students in order to provide an insight into the act of knowing. This favors 
the cognitive development along with socio-emotional skills, and resumes the formation of the students, allowing the development of both conceptions simultaneously (Morin, 1990).

A project that shares tasks promotes the soft skills of each student, as it develops the self-esteem and the integration of the children in school and other places. The activities work out in the project should be stimulating and include constructions, readings, oral presentations, written expositions, games, and spontaneous creations, since they are important soft skills to learn.

Under the same way each project starts in a planned manner, it should be evaluated in terms of its scope and efficiency. Thus, it is important that teachers have different instruments to evaluate the development of the students and the project. This type of pedagogical action requires teachers to be mediators of the activities, favoring the students' active learning (Perrenoud, 2001).

Furthermore, this pedagogical work supports the construction of a pleasant and intelligent school environment, before the arrival of the students and they're staying in the school, as well as during the work of the teacher and the school management team (Libâneo, 1998).

By thinking in the teachers in their school environment, it is easy to notice the discrepancies they are submitted from day to day. If, on one hand, it is discussed and encouraged to have a critical view of the school environment, on the other hand, teacher's routine disfavors that (Libâneo, 1998).

Aware of these difficulties on the teacher's daily life, Active Learning Methodologies are useful to overcome them. One of them is the Project-Based Learning (BPL), which is addressed in this report.

\section{Project-Based Learning (PBL)}

An effective teaching-learning strategy to develop both socio-emotional skills and students committed to the environment seems to be the PBL methodology. Under this educational context, students are allowed to confront issues of their daily life, seeking solutions to those issues, preferably in teams (Masson et al., 2012).

PBL requires commitment and greater responsibility, not only from the students, but also from the teachers. This methodology helps to reflect that the teaching-learning activity should not be based upon the traditional teaching practice, in which teacher is a couch of learning. Students become active and primarily responsible for their own learning, and must understand that the knowledge obtained by their own personal efforts will have much more meaningful (Markham et al., 2008).

For the effectiveness of the PBL methodology, it is necessary to know clearly that the work in teams will start with the previous knowledge of the students and the development must take into account two main aspects: 1) The elaboration of activities, which can promote the resolution of a problem or increase the knowledge on a certain matter; and 2) The elaboration of a final product, which 
should be a result of the whole process overcame by the students during the project (Helle et al., 2006).

According to Markham et al. (2008), the main characteristics of interdisciplinary projects based upon PBL, aiming to guarantee the success of student's learning, are:

1) Recognizing the impulse to learn, placing students at the center of the learning process;

2) Involving students in the central theme of the project,

3) Highlighting provocative and important issues,

4) Developing skills to manage the projects,

5) Presentation of the information obtained through search and reasoning,

6) Developing products in which students learn through experience,

7) Developing skills and knowledge based upon challenges, and

8) Stimulating teamwork through collaboration.

However, prior to the execution of the project, in which above listed features must be present, it is necessary to rethink upon some criteria for its elaboration.

Thus, it is fundamental to reflect on how the development of the project will be carried out in the daily life of the students who will perform it, giving an authentic characteristic to the whole process. Furthermore, one must think about the development of the soft skills that, while difficult to measure, are of great importance for the personal student's development.

Finally, as a conclusion of the whole process, the evaluation of the practice (Markham et al., 2008), which requires self-reflection, reflection on teamwork, and reflection on the conduction of the project, is as one of the most difficult step to obtain good results because of the subjectivity (Helle et al., 2006).

\section{Context of Study}

\subsection{Project, School, and Subject of Study}

The present work was carried out in a class of 17 students of the 4th grade of Elementary School at the Taubaté town, São Paulo State, Brazil, between April and June of 2018. Initially, the class had 16 students engaged, but after the sixth stage, another student became part of it.

The spaces available in the school were suitable for learning, since they included computer rooms, science labs, toy library, English environment room, specialized educational service room, and multi-sport courts.

The student group had different personality profiles, but with a wide interest in several fields of knowledge, especially in the biological science.

The students had a teacher responsible for managing the class most of the time and for establishing frequent contact with their parents. To refer to this teacher, the term regent teacher has been used. In addition to the classes taught by the regent teacher, students also had classes in Computer Science, Art, Physical Education, and English given by teachers specialized in those subjects. The regent teacher has graduation in pedagogy and specialization in Libras (Acronym 
in Portuguese for Brazilian language of signals) and psycho-pedagogy. She has worked in the area of Education for about 12 years and has worked as a pedagogical coordinator in this and other schools. For the class referred to this work, the regent teacher gives classes on Portuguese, Mathematics, Science, Geography, History, and Philosophy subjects.

Keeping in mind the developing of both socio-emotional skills and the concepts related to the harmful effects of noise pollution, an educational project was carried out with the students. The main objective was to discuss concepts related to noise pollution in order to develop citizens committed to the environmental preservation. To do so, it was identified what students already knew about the subject and after that, some activities of investigation, auditory acuity, and presentation of works were performed.

\subsection{The Application Routine}

The project was developed in eight stages carried out between April and June of 2018. Each stage lasted approximately one hour and forty minutes. Records were made at the end of each stage in order to register the most relevant data. A description of each of the stage is given below.

Stage 1-First evaluation:

This stage was intended to find out what the students know about the term "Pollution" through a written evaluation. Each student received a paper sheet containing two questions. The first one had pictures of pollution, in which students were asked to list the items that showed pollution in the environment. The second question, which had a discursive character, was composed of the following question: "What do you mean by pollution?" In that question, students should give detailed information on their previous knowledge on the subject.

Stage 2-Investigative activity:

Students were divided into four teams with four students each. The division was made based upon the socio-emotional skills of each student according to the regent teacher's perception, in order to assure different profiles in the same team. Then, the four teams went to the school's computer lab to search the internet about the types of pollution that exist and to take note of the information found to prepare a talk to be presented to the class at the end of the activities of this stage.

Stage 3-Home to School trip:

In teams, students were invited to post photos, videos, and drawings of polluting elements they observed on their way from home to school. Observations should be sent to the regent teacher through mobile e-message applicative. As the students were related to an Elementary School, parents were advised that the use of technological tools would be allowed during the observation week. After the data collection period, the teams met again in order to elaborate a visual and oral presentation of the elements collected. To do so, they should select videos and images, and use the information previously collected in the computer lab (Stage 2). 
Stage 4-"Cleaning the Ears" activity:

Because of the excess of noise, in general, individuals have difficulty distinguishing noises from pleasant sounds. For the development of this perception, it is necessary to perform a "Cleaning the Ears", which is a sequence of activities to train auditory acuity (Schafer, 1991: p. 66).

Two activities were carried out during this stage:

1) Students were led by the musical teacher to perceive the production of noise after a period of silence. Everyone should pay attention to the sounds they would hear during a minute and classify them as natural, human being, and technological sounds. Then, they received an explanation about the parameters of sound: a) duration (continuous, repetitive, or unique); b) intensity (loud and weak sounds); and c) timbre (bass or treble), and were assigned again to classify the sounds within the patterns discussed; and

2) In order to demonstrate the importance of silence in activities involving attention, students received the task of memorizing a sequence of six pictures shown by the regent teacher, with sound interference (sounds of rattles and musical sounds) and should record the sequence as they remembered. Then, the teacher showed six new pictures, but in silence, and the students should take note again on their observations for comparison with the first record.

This stage was applied by the regent teacher along with two other teachers, one related to the music subject and another biological science subject.

Stage 5-Forest in the classroom:

After the activity "Cleaning the Ears", students joined the initial teams and received a virtual reality glasses with the mobile applicative "VR Adventure", which contained 3D videos regarding natural environment. After all the students watched the video, the music teacher, positioned in the center of the classroom, played various sounds of the forest, including sounds of flora and fauna, with the help of another mobile applicative called "Sounds of Nature", which has acoustic sounds of the natural environments. Then, each team received a paper sheet, in which they had to express, in drawing form, the pictures they have visualized in the video while hearing all the sounds played during the activity.

Stage 6-Finding sound measures in the school spaces:

The unit of measurement that allows estimating the sounds of an environment, the decibel $(\mathrm{dB})$, was presented to the students during this stage. The students, in their respective teams, selected four environments to measure noise using and Sound Meter applicative available in smartphones, which was characterized as an instrument for measuring the sound level. The students compared their results.

At this stage, another student joined the class.

Stage 7-Prototype-“Sonorous landscape":

The prototype, in the PBL, is a product, service or process that represents all the concepts approached during the project process (Plattner, Meinel, \& Leifer, 2011).

To present a product that marks the ending of the project, the students col- 
lected reusable materials and created a musical wind instrument that should take into account the perception of noise and sound parameters. The students called this instrument as "hidrofone". Thus, they were able to contextualize the information about the sound parameters: duration, intensity, and timbre.

The elaboration of this "Sonorous landscape" carried out by means of an unconventional music sheet, which directed the execution of the musical piece. Initially, each team created its sound sequence. Then, the notes and arrangements were made by the teams in order to produce a unique musical piece, which was played by all in a single group.

Stage 8-Evaluation, Self-evaluation, Team evaluation, and Project evaluation:

This stage was divided into four distinct activities.

The first one consisted of meeting students in their teams to answer collectively the same questions discussed in the first stage.

The second was an individual self-evaluation, in which each student assigned the conceptions of responsibility, collaboration, and interpersonal relationship.

Then, the same items were used to evaluate each member by the team. The team evaluated each member collectively.

Finally, the project evaluation was based upon a quiz with four questions, which were answered using the Likert scale (Likert, 1932).

\section{Results and Discussion}

\subsection{Conceptual Evaluation}

According to the results of the first evaluation, it was noticed that in the first question 12 students were able to identify correctly all the pictures about noise pollution, 2 students identified two pictures, 1 student noticed 1 picture, and 1 student was not able to identify any picture. Regarding the discursive question, it was observed that 11 students cited noise pollution in their answers and 5 students did not record this type of pollution.

Although some students included the term "sound pollution" in their discursive answers, they were not able to associate it with the pictures that showed excessive sound. Another relevant aspect was the fact that some students recognized noise as a "pollutant element", but in the discursive question, they did not use the term "pollution".

This same evaluation was applied in stage 8 to be answered by each of the teams in a collective way. At the end of the project, it was observed that all the teams identified properly both "sound pollution" expression and pictures that portrayed it.

\subsection{Working with Noises and Sounds}

The fourth, fifth, sixth, and seventh stages were dedicated to the exploration of noise and sound, since anywhere the sound landscape is changing. Sounds are multiplying even faster than people are as we surround ourselves with more mechanical devices. This fact produces noisier environments, which can lead to 
the deafening of modern civilization (Schafer, 1991).

In Stage 4, during the activity of memorizing the pictures under sound interference, it was verified difficulties for the students to correct identify the pictures. Most of them (9 students) identified up to two pictures and only 2 students were able to correct identify the sequence of all pictures. Then, in the silent memorization, an improvement on the results was clearly observed. $5 \mathrm{stu}$ dents correctly identified the sequence of 4 pictures; 3 students identified 5 pictures, and 4 students identified the sequence of all pictures in their proper order. Figure 1 shows a comparison between the results obtained with noise and with the class in silence.

In Stage 5, in which the teams should report the visual and sound elements watched and listened through drawings, it was verified that the Team 1 presented the drawing with a great number of details and developed all the tasks without any personal conflict, but with little collaborative interaction between the members. Team 2 was able to report a reasonable number of elements, but there was no interaction between the students, and only one of them was in charge of all the work. In Team 3, there was disagreement between the students and only half of them made the final work with a considerable number of elements portrayed. Finally, Team 4 was the only one that showed the best performance in the collective work by sharing the tasks among its members, although it was not the one that most portrayed the elements. The interesting thing about this activity was the difficulty that the students presented in working under harmonious way in the teams. One possible explanation for this may be the fact that they are children and is difficult to establish and keep a leader for the team.

The sixth stage provided students with a discussion about noise in the school environments. They analyzed and measured the noise in the computer lab, library, sports court, and a hall during the break time. The quieter environment was the library, as they predicted, and the louder place was the sports court. Table 1 shows the noise measured in the four school environments.

At that level, students were already familiar with the concept of "noise pollution" and its harmful effects, and highlighted the issue of environmental preservation, especially with regard to sound landscape.

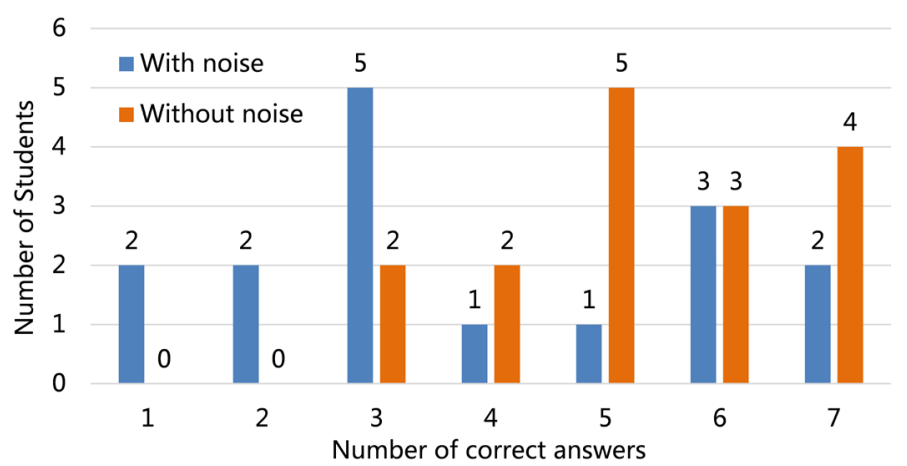

Figure 1. Memorization of the sequence of pictures by the students under and without the influence of noise in the classroom. 
Table 1. Measurement of noise in different school environments.

\begin{tabular}{cc}
\hline Local & Noise level (dB) \\
\hline Library & 25 \\
Computer lab & 42 \\
Hall & 42 \\
Sports court & 43 \\
\hline
\end{tabular}

Source: Authors.

In Stage 7, the students used the musical instrument "Hidrofone" to exercise the parameters of sounding through the elaboration of a musical piece. By this, they were able to reflect on the characteristics of noise and sound, as well as the sound classification (Wisnik, 1989). They realized that the instrument made out only emitted noise. However, when organized, it produced a pleasant sound effect. It was also highlighted that the preparation of the instrument gave the students a reflection about the reuse of materials considered disposable.

\subsection{Socio-Emotional Skills and Work in Teams}

Social-emotional skills were present at all stages and served as a basis for developing the concept of "pollution". In order to discuss these skills, the data about self-evaluation and evaluation of the members of each team were recorded and analyzed.

For the analysis of the self-evaluation were considered the following soft skill: responsibility, interpersonal relationship, and collaboration. The assignment of concepts was given by importance: 1 (insufficient), 2 (good), and 3 (very good). The results obtained are shown in Figure 2.

The results show that most of the students evaluated themselves as very good in the three soft skills. Interesting is the fact that no student considered him/herself insufficient in any of the skills.

Table 2 reports the evaluation of the social-emotional skills. The students in their own teams evaluated these skills. During the evaluation of each component of the team, the same skills and assignment of concepts were established.

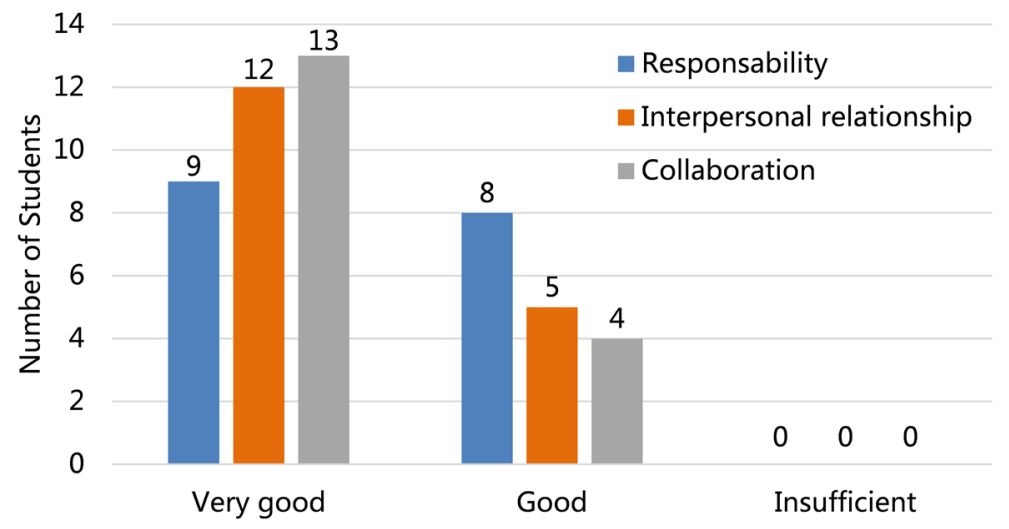

Figure 2. Students self-evaluation on their socio-emotional skills. 
It is noted that the student's perception of the collaboration is one in which their colleagues performed better. This result suggests an active positioning of most of the components of the team in front of the project stages. Despite this result, the average observed in responsibility reveals that the teams expected their components not only to collaborate but also to engage in the tasks. The data reported in Table 2 show that students had perception between good or very good, which suggest developments of their socio-emotional skills during the execution of the project reported here. These observations do not completely agree to the perceptions reported in stage 5 .

Table 2. Evaluation of the socio-emotional skills by the teams. 1, 2, and 3 indicate, respectively, insufficient, good, and very good.

\begin{tabular}{cccc}
\hline Team & Collaboration & Responsibility & Interpersonal relationship \\
\hline 1 & $2.6 \pm 0.3$ & $2.0 \pm 0.7$ & $2.4 \pm 0.5$ \\
2 & $2.5 \pm 0.5$ & $2.0 \pm 0.8$ & $2.5 \pm 1.0$ \\
3 & $2.3 \pm 0.2$ & $2.3 \pm 0.5$ & $2.3 \pm 0.5$ \\
4 & $3.0 \pm 0.1$ & $2.5 \pm 0.6$ & $2.5 \pm 0.6$ \\
\hline
\end{tabular}

Source: Authors.

\subsection{Project Evaluation}

The project evaluation was done using the "Likert" scale with a 3-point measurement, as "I totally agree" (A), "partially agree" (B), and "do not agree" (C). The results are shown in Table 3.

In general, it was observed by students that the project contributed to increasing the knowledge of the types of pollution. They also emphasized that the project helped them in changing their posture regarding the harm of sound pollution, as well as helped to understand the importance of preserving the nature environments. These considerations allow us to verify that PBL is, in fact, an active learning methodology that provides participants, even children, with action and reflection on the subjects to be learned.

Table 3. Evaluation of the project. A, B and C indicate, respectively, "I totally agree", "I partially agree", and "I do not agree".

\begin{tabular}{cccc}
\hline Issue & A & B & C \\
\hline The project contributed to increasing my knowledge about pollution & 14 & 3 & 0 \\
The project has helped me to be aware of the types of noise & 9 & 7 & 1 \\
The project contributed to preserving natural environments & 9 & 7 & 1 \\
Because of the project, I began to enjoy sounds of natural environments & 9 & 4 & 4 \\
\hline
\end{tabular}

Source: Authors.

\section{Final Remarks}

It is known that acoustic ecological preservation is interested in the relationship 
between sounds and the environment. When this relationship is not balanced, there exists noise pollution. This subject is very important in the contemporary life and cannot be ignored, because people are living exposed to excessive noisy environments, which constitute a real threat to our hearing and health. Based upon such conceptual aspects, this report described an application of PBL that aimed not only on the development of technical competences, but also at the socio-emotional skills.

Social-emotional skills were present at all stages and served as background for the development of the concept of "pollution" in a more general way. It was observed several times that the students needed balance in dealing with other members of their team and assisting them in understanding the central concept of the project. It was also noticed that, in most of the classes, there was a change of posture, as expected in the project. Another important point was the student's perception about themselves and about their peers in the team, which was clear in the evaluations and self-evaluations.

Finally, it was noticed that the project, by providing that the students were the most important agent in their own learning, allowed a reflection on the noise as a polluting element. On this context, the role of each one in the preservation of the environment was highlighted corroborating to the integral education.

\section{Conflicts of Interest}

The authors declare no conflicts of interest regarding the publication of this paper.

\section{References}

Eniz, A. O. (2004). Poluição Sonora em Escolas do Distrito Federal (p. 111). Dissertação de Mestrado, Brasilia: Universidade Católica de Brasília.

Grün, M. (1996). Ética e educação ambiental: A conexão necessária. São Paulo: Papirus.

Helle, L., Tynjälä, P., \& Olkinuora, E. (2006). Project-Based Learning in Post-Secondary Education-Theory, Practice and Rubber Sling Shots. Higher Education, 51, 287-314. https://doi.org/10.1007/s10734-004-6386-5

Libâneo, J. C. (1998). Pedagogia e pedagogos, para quê? São Paulo: Cortez.

Lima, P. A., Judice, M. G., \& Reys, P. (2014). Comparação dos Níveis de Poluição Sonora em Diferentes Ambientes da Universidade de Rio Verde-GO (p. 10). Monografia de Graduação, Rio Verde: Universidade de Rio Verde.

Likert, R. (1932). A Technique for the Measurement of Attitudes. Archives of Psychology, 22, 44-53.

Machado, A. A. (2004). Poluição sonora como crime ambiental (No. 327). Teresina: Revista Jus Navigandi.

Markham, T., Larmer, J., \& Ravitz, J. (2008). Aprendizagem baseada em projetos: Guia para professores de ensino fundamental e médio (2nd ed.). Porto Alegre: Artmed.

Masson, T. J., Miranda, L. F., Munhoz Jr., A. H., \& Castanheira, A. M. P. (2012). Metodologia de Ensino: Aprendizagem Baseada em Projetos (PBL). Belém: Congresso Brasileiro de Educação em Engenharia.

Medeiros, A. B., Mendonça, M. J. S. L., Sousa, G. L., \& Oliveira, I. P. (2011). A Im- 
portância da educação ambiental na escola nas séries iniciais. Revista Faculdade Montes Belos, 4, 1-17.

Morin, E. (1990). Introdução ao pensamento complexo (2nd ed.). Tradução Dulce Matos, Lisboa: Instituto Piaget.

Perrenoud, P. (2001). A Pedagogia na Escola das Diferenças. Artmed Editora.

Plattner, H., Meinel, C., \& Leifer, L. (2011). Design Thinking. Berlin: Springer. https://doi.org/10.1007/978-3-642-21643-5

Rampazzo, S. E. (1996). A questão ambiental no contexto do desenvolvimento econômico. Redes, Santa Cruz do Sul, 1, 197-222.

Rios, A. N. (2003). Efeito do Ruído Tardio na Audição e na Qualidade do Sono em Indivíduos Expostos a Níveis Elevados. Dissertação (Mestrado), Ribeirão Preto: Faculdade de Medicina da USP.

Schafer, R. (2009). Murray. Educação Sonora. Educação Musical (Trad. Fonterrada, M.). Melhoramentos.

Schafer, R. (2001). A afinação do Mundo (Trad. Fonterrada, M.). São Paulo: UNESP.

Schafer, R. (1991). O Ouvido Pensante: Música e Ensino (Trad. Fonterrada, M.). São Paulo: UNESP.

Zajarkiewicch, D. F. B. (2010). Poluição Sonora Urbana: Principais Fontes-Aspectos Jurídicos e técnicos. São Paulo.

Wisnik, J. M. (1989). O Som e o Sentido. Uma outra história das Músicas. São Paulo: Companhia das Letras. 